\title{
Research Note: $\quad$ FLD on INM: A tool to optimize nutrient use and improvement of brinjal yield
}

\section{B.M. TANDEL, K.A. SHAH, PRABHU NAYAKA AND C.K. TIMBADIA}

Article Chronicle: Received :

01.05.2015;

Accepted :

15.08.2015

KEY WORDS :

INM, Brinjal,

Management,

Nutrient management
SUMMARY : Front line demonstration (FLD) is one of the most powerful tools for transfer of technology. In order to increase the productivity of brinjal (Solanum melongena L.) by adopting improved technologies, several demonstrations with scientific package of practices were conducted by Krishi Vigyan Kendra, Navsari. Since five years about 97 FLD's on INM brinjal were under taken. A study on impact of farmer's knowledge, adoption and knowledge regarding scientific innovations was conducted. The impact assessment was based on the comparison of before contact and after contact of KVK with reference to increase in knowledge level of farmer's regarding scientific packages of practices, extent of adoption of INM technology. It was found that the overall knowledge of INM demonstrations indicated that low, medium and high level of knowledge before contact with the KVK was 49, 38 and 13 per cent, respectively. It was altered upto 08,50 and 42 per cent, respectively after contact with the KVK. In case of knowledge regarding selected scientific innovations for demonstrations high knowledge regarding selected scientific innovations were found except IPM (17\%). It can be suggested that FLDs in the south Gujarat region found to be an important constraints and were ranked in first position which needs to be solved for betterment of the tribes in this region.

How to cite this article : Tandel, B.M., Shah, K.A., Nayaka, Prabhu and Timbadia, C.K. (2015). FLD on INM: A tool to optimize nutrient use and improvement of brinjal yield. Agric. Update, 10(3): 282-284.
Author for correspondence :

\section{B.M. TANDEL}

Krishi Vigyan Kendra, (N.A.U.), NAVSARI (GUJARAT) INDIA

See end of the article for authors' affiliations 